\title{
INVESTIGATING THE CURRENT BUSINESS MODEL INNOVATION TRENDS IN THE BIOTECHNOLOGY INDUSTRY
}

\author{
Balint HORVATH ${ }^{1}$, Nesrine KHAZAMI ${ }^{2}$, Prespa YMERI ${ }^{3}$, \\ Csaba FOGARASSY ${ }^{*}$ \\ ${ }^{1}$ Climate Change Economics Research Centre, Szent István University, Hungary \\ 2, ${ }^{3}$ Doctoral School of Management and Business Administration, Szent István University, Hungary \\ ${ }^{4}$ Climate Change Economics Research Centre, Szent István University, \\ Páter Károly 1, Godollo 2100, Hungary
}

Received 05 September 2018; accepted 12 November 2018

\begin{abstract}
The current trend of business model research shows an increased endeavour of conceptualizing business frameworks for circular economy (CE). While previous sustainability paradigms have failed to attract market stakeholders, their reaction differ regarding this concept. The reason is discovering that the benefits of former industrial systems have turned to be threats for modern companies. Thus, a circular transition seems beneficial not only in environmental but also in financial dimensions. Closing material and energy flows results in reduced costs and enables businesses to propose novel values to customers. The present study aims to investigate the current stage of circular transformation on a corporate level. In order to do that, it thoroughly analyses the business model evolution of an innovative and knowledge-intensive industry, biotechnology. The research employs a circular evaluation method to detect which parts of the applied business structures show the signs of transition. The findings indicate that the business innovation process in the sector is in line with the disciplines of $\mathrm{CE}$. However, this phenomenon is rather the result of striving for market competitiveness, than making efforts for sustainable development. It proves the emergence of CE to be as much an economic concern as it is an environmental one.
\end{abstract}

Keywords: business model innovation, circular economy, biotechnology, SME, circular value proposition.

JEL Classification: M21, M14, Q56.

\section{Introduction}

As the narrow perspective of mainstream economic practices has led to the degradation of earth's natural ecosystems, businesses have been challenged for decades to steer their operations in a sustainable direction. However, the notion of "sustainability" has always had a deceptive recognition in the world of business. Schaltegger, Hansen, and Lüdeke-Freund (2016)

*Corresponding author. E-mail: fogarassy.csaba@gtk.szie.hu 
differentiate a "sustainable business" from a "business for sustainability". While the former only means a financially stable initiative, the latter extends its value proposition towards environmental and social horizons. The same authors have also stated that business model innovation must play an essential role in establishing corporate sustainability (Schaltegger, Lüdeke-Freund, \& Hansen, 2012). The reason is that structural amendments of an enterprise have become more significant to ensure market competitiveness, than the previously applied product development (Chesbrough \& Rosenbloom, 2002). This perception has become the foundation of business model research which has been a significant study area in the past 15 years.

Amit and Zott (2012) argue that the importance of redesigning businesses has gained increased attention due to advancing information technology (IT). The application of novel IT tools has opened new channels to collaborate with partners and to reach customers. Thus, incremental innovation has become a lower priority comparing to business model generation (Osterwalder \& Pigneur, 2010). Chesbrough (2010) directly states that a superior business model around an ordinary product is a better combination than a great product utilized within a mediocre business model. Zott, Amit, and Massa (2011) support this idea by claiming that products must be always complemented with proper business structures. Although this research area has received several contributions over the years, the core concept still lacks a comprehensive elaboration. The most accurate description comes from Teece (2010), who sees the notion of business models as a collective umbrella of value creation, delivery and capture mechanisms. According to him, a business must clearly discover customer needs and find a way to respond to them. Then, it turns customer payments into profits by orchestrating the certain components of the value chain accordingly.

The increasing role of business design explains the intention of Schaltegger et al. (2012) to use it for implementing corporate sustainability. In the past years, several authors (Gauthier \& Gilomen, 2016; Breitbarth, Schaltegger, \& Mahon, 2018) reported practical experiences of successful businesses providing social and environmental values while gaining financial benefits as well. Nevertheless, achieving sustainable goals through business models is still up for debate. Johnson, Christensen, and Kagermann (2008) have investigated motives for rethinking business structures and found only economic incentives to engage in it. ArmasCruz, Gil-Soto, and Oreja-Rodríguez (2017) have focused on the possibilities of spreading green businesses and concluded that the simple profitability of such initiatives does not give motivation for corporate decision makers to move from business as usual (BAU) practices. The same thought is supported by Fogarassy, Horvath, and Magda (2017b), who argue that traditional businesses react only to emerging market needs. Thus, the transformation of the mainstream economic thinking must offer higher financial values comparing to the former system. Otherwise, businesses for sustainability will remain single case studies, instead of becoming trends.

This idea aligns with the argument of Ramkumar et al. (2018) who observe environmental solutions as answers to surfacing market expectations, rather than additional functions. The authors state that the current benefits of BAU processes will soon turn into threats to companies due to several aspects. These are for instance the emerging scarcity of primary resources; price volatility of these resources; supply chain inefficiencies; bans on the trade of 
waste; decreasing costs of renewable energies etc. They collectively refer to these patterns as "linear risks". The term means the exposure to an economic paradigm which still clings to the benefits of previous industrial revolutions. Recent studies (Brooks et al., 2018; Horvath, Mallinguh, \& Fogarassy, 2018) support this perspective by claiming that the profitability of the reigning economic regime lies in outsourced externalities. It is cheaper to waste resources, than to track their flow and recover them eventually. However, this status quo seems to collapse as influential stakeholders (e.g. China, Kenya) are about to quit waste markets. Based on these discoveries, moving on from the "take-make-dispose" perspective and creating a closed resource loop will be an essential requirement for companies and economies in general. For this reason, the European Commission (2015) has released its closed loop action plan which urges the transition to a circular economy (CE).

The CE concept refuses the traditional features of economic growth (e.g. mass production, utilization of scarce and non-renewable resources, producing non-durable goods etc.) and offers innovative solutions to preserve natural capital and to enhance social welfare. Its top priority is to achieve the lowest possible material and energy flow through economic processes and to avoid resource leakages (Ellen MacArthur Foundation, 2015a). In contrast to previous sustainability endeavors, these initiatives receive increased attention from the business sector. According to a recent study of the World Business Council for Sustainable Development (WBCSD), 80\% of the surveyed companies highlighted the acceleration of growth and the enhancement of competitiveness as drivers to adapt circular strategies. The remaining 20\% indicated risk mitigation as the main motive to develop a circular business model (WBCSD, 2017). These findings also imply, that CE has reached the field of business model research as well.

In defining the notion of circular business models, Scott (2013) argues that such initiatives must either employ recoverable biological materials or continuously reuse their technical materials. Both activities are expected to leave ecosystems without any harm or waste. Mentink (2014) claims that circular businesses must create and capture value within closed material loops. The same author highlights a key feature by stating that a business model alone cannot be circular. Closing the loop is rather achieved through a collaborative network of businesses. Bocken, Rana, and Short (2015) classifies circular businesses based on their environmental strategies. They found that companies can influence resource loops through three different methods. The first option is to slow resource flows by the extension of product use. This pattern requires the design of durable goods. Another way is the closure of loops through recycling materials. The last solution is to narrow loops which means the reduction of resource utilization. Comprehensively, Lewandowski (2016) recognizes businesses as circular if their model involves essential CE characteristics (e.g. resource optimization, loop closure etc.).

So far, this paper presented two notable concepts: business model design and circular economy. Kraaijenhagen, van Open, and Bocken (2016) states that their mutual application is inevitable for two reasons. On one hand, an economy-wide circular transition cannot be conducted without such bottom-up initiatives. On the other hand, business models can only function efficiently if they apply circular features. Manninen et al. (2017) support this statement and claim that the recent academic activity shows an increasing interest towards 
circular business model development. However, they also find that this unilateral focus leaves a gap in the literature for the assessment of such models. The present research adds to this problem that the previous contributions lack the investigation of circular progress on business level. If corporate stakeholders truly perceive CE as something more than another sustainable paradigm and consider it as an essential market need, they must have started the transition process already. Therefore, this study aims to evaluate business models in respect of their fit to CE. Certain studies (Ellen MacArthur Foundation, 2015b; Aminoff, Valkokari, Antikainen, \& Kettunen, 2017) have assumed that such transformations would start in the most knowledge-intensive and innovative industries. Thus, the present analysis narrows down its focus to one particular sector, biotechnology. That industry is predicted to be the backbone of the upcoming economic era (Allianz, 2010); received the second highest amount of global investments in 2015 (Ernst \& Young, 2017); and shows an intense level of business model generation (Segers, 2015).

Through the examination of the new generation biotech business models, the purpose of this paper is to answer the following research question: at which stage does the circular progress stand on a business level? In order to do that, it conducts a comprehensive literature review on the evolution of biotech business models. Moreover, the analysis will employ an evaluation criteria on these models to assess their circular performance. Besides detecting the level of circularity at biotech businesses, the added value of the research will be to generate a best practice model for companies who tend to engage in such transitions. The structure of the paper will be as follows: section 2 reviews the business models of an advanced biotech ecosystem according to a circular methodological criteria. Section 3 first presents the results of the evaluation, then summarizes the detected circular elements of the analysed models.

\section{Materials and methods}

Before the thorough analysis, the subject of the research must be narrowed further because the biotechnology industry contains a diverse set of several branches. According to Pisano (2006), the biotechnology industry must be distinguished into pharmaceutical and non-pharmaceutical companies. This is due to their extremely varying features. Non-pharmaceutical biotech firms are in a relatively better position, since they generate results earlier than pharmaceutical businesses. While the research and development (R\&D) period for non-pharma initiatives can be completed within several years (or even in months), the average duration of the same activity lasts 10-20 years for pharma institutions. Tölle and Herbst (2016) highlights that another risk factor is that product development can fail at any time within this interval. Pharmaceutical products have strict regulations which require different discovery, preclinical and clinical test stages. Therefore, the standards of introducing a new drug to the market are high and the average cost of a full product development is around 900 million USD. According to the trends of the past 15 years, on average only 1 out of 10 drugs in average received approval in the EU and in the US (Kola \& Landis, 2004; Hay, Thomas, Craighead, Economides, \& Rosenthal, 2014). Eventually, the pharmaceutical branch is highly competitive and must almost entirely rely on private funding. This situation affect small and medium-sized enterprises (SME) the most because they receive only a minor amount from 
investments and barely make actual incomes (Micek, Gleadle, \& Dawidko, 2014). However, Sabatier, Craig-Kennard, and Mangematin (2012) states that starting companies face similar circumstances in any other sectors and urges pharmaceutical firms to answer these challenges by rethinking their business models.

Currently, the best study area to investigate best practices for such models is definitely Belgium (Doranova, 2016). Belgium has a 286 million EUR market capitalization of small biotech companies which is the second largest amount in Europe. 7 out of Europe's top 10 revenue-generating biotech companies are located in that country and the world's 10 most influential biopharma actors run key activities there. The biopharma firms of Belgium represented $18 \%$ of the European biotech market capitalization with 21.5 billion EUR in 2016 . The cumulative value of licensing and R\&D contracts was more than 18 billion EUR in the past 12 years. The biotech industry of the country spent 3.4 billion EUR on R\&D in 2016 which was a $+123 \%$ increase compared to 2006 . This superior biotech ecosystem lies in a strong academic background and innovative SME community. Moreover, the national regulations and financial incentives are quite supportive. The Belgian law allows companies to finish Phase I trials within 15 days which results in a top European position regarding the number of clinical trials. Eventually, Belgium is 2nd in the EU concerning the number of trials per capita (Essenscia, 2017).

Segers (2017) has extensively analyzed the Belgian pharmaceutical biotech industry and identified 22 different business model types. According to his observations, companies use the combination of the certain models. He has recognized that the trigger of evolutional breakthrough at biotech businesses was engaging in collaborative networks. Therefore, his main grouping discipline throughout the classification was the manner of firms towards sharing innovation. Based on this pattern, one can distinguish between closed and open business models. The present research reviews the Belgian biotech business models according to this organizational logic. Closed models are built on a structure which considerably relies on internal resources and most importantly, on own knowledge. It is the conventional form of biotech business models. However, the current trends show that large firms outsource certain activities to better focus on their core profile. This phenomenon opens room for sharing innovation and developing open business models. Moreover, it highlights the importance of small ventures which contribute to the creation of a business ecosystem. Since the initial literature emphasizes the significant role of SMEs and urges the need for business model innovation in their operation, they prove to be a suitable subject to the case study. Thus, the research will be built on detecting such circular features in pharmaceutical businesses that would be applicable for start-ups and SMEs.

Concerning the methodological background, the analysis evaluates the identified business models according to the Ellen MacArthur Foundation's (2013) circular assessment criteria. Lewandowski (2016) has offered a conceptual basis for building circular businesses models in which he has put emphasis on the foundation's ReSOLVE (regenerate, share, optimize, loop, virtualize, exchange) framework. That method is based on locating circular elements in business models to define their fit to CE. Table 1 gives a detailed description about the framework's components. 
Table 1. The modified ReSOLVE framework (source: self-made based on Ellen MacArthur Foundation (2013) and Lewandowski (2016))

\begin{tabular}{|l|l|}
\hline \multicolumn{1}{|c|}{ Activity } & \multicolumn{1}{c|}{ Description } \\
\hline \multirow{3}{*}{ Regenerate } & use renewable energy and materials \\
\cline { 2 - 2 } & reclaim, retain and regenerate health of ecosystems \\
\cline { 2 - 2 } & return recovered biological resources to the biosphere \\
\hline \multirow{2}{*}{ Share } & enhancing product utility by sharing the use, access or ownership \\
\cline { 2 - 2 } & $\begin{array}{l}\text { extending product life through reuse, maintenance (e.g. repair, refurbish) or design } \\
\text { for durability }\end{array}$ \\
\hline \multirow{2}{*}{ Optimize } & $\begin{array}{l}\text { optimisation of resource use through increasing performance or outsourcing ac- } \\
\text { tivities }\end{array}$ \\
\cline { 2 - 2 } & remove waste in production and supply chain \\
\hline Loop & close material loops by remanufacturing, repurposing, recycling or recovering \\
\hline Virtualize & dematerialize products or services through digital appliances \\
\hline Exchange & employ new technologies, materials or processes \\
\hline
\end{tabular}

Based on the introduced circular criteria, Table 2 presents an overview of the first generation (the closed models) of pharmaceutical businesses and highlights their key patterns fitting $\mathrm{CE}$ requirements. The first three models are the traditional forms of biotech companies. The common feature of the rest is that they are suitable for starting enterprises struggling with a lack of financial capital. They operate in early stages of the value chain and try to grow by monetizing their intellectual property or providing services. Their only CE fit is their service provision to big companies which falls under the umbrella of sharing principles. An appealing exception is the 'No research - development only' model which deliberately positions itself at the end of the value chain. That initiative provides a biotech metaphor for one of circular economy's top priority: the lifespan extension by reuse. When a large company discards a drug at a late stage of development, it results in loss of all the previously manifested energy and material. That model is able to save all these efforts through buying such drugs and completing the research on them. That example indicates a useful element that could be applied in novel initiatives. In general, the presented business models are considered conventional due to their lack of collaboration in the field of innovation.

The paradigm shift in the biotech industry has occurred with the appearance of open business models by the turn of the century. It has enabled companies to focus extensively on their core competencies by outsourcing (part of) their R\&D activities (Chesbrough, 2007). The employment of external resources by large firms has allowed small businesses and start-ups to enter the market by targeting particular niches in the value chain. Nowadays, the presence of such SMEs is not only practical but highly relevant in the whole economy (Blecharz \& Stverkova, 2014; Wach, 2015). In biotechnology, they contribute to the creation of a business ecosystem where innovation is conducted through a collaborative network of firms with varying sizes and specializations. This mechanism reduces operation costs and value chain dependence. Furthermore, it opens new revenue channels by connecting its actors to a global market. 
Table 2. The closed business models of the Belgian pharmaceutical biotech industry (source: self-made based on Segers, 2017)

\begin{tabular}{|c|c|c|}
\hline Business model & Characteristics & $\begin{array}{l}\text { Applica- } \\
\text { bility }\end{array}$ \\
\hline Product-based & $\begin{array}{l}\text { - Vertical integration, } \\
\text { - Full control on value chain, } \\
\text { - High capital requirement, } \\
\text { - Model for large companies. }\end{array}$ & $\begin{array}{c}0 \\
-1 \\
-1 \\
-1\end{array}$ \\
\hline Platform-based & $\begin{array}{l}\text { - Focuses on early stage research, } \\
\text { - Develops research tools or platform technology to license it to } \\
\text { other companies, } \\
\text { - Less risk, } \\
\text { - Lower capital need. }\end{array}$ & $\begin{array}{c}0 \\
+1 \\
0 \\
0\end{array}$ \\
\hline Hybrid & $\begin{array}{l}\text { - Mixture of product- and platform-based models, } \\
\text { - Provides service and engages in later product development, } \\
\text { - Opportunity for short-term revenues. }\end{array}$ & $\begin{array}{c}0 \\
+1 \\
0\end{array}$ \\
\hline $\begin{array}{l}\text { Royalty Income } \\
\text { Pharmaceutical } \\
\text { Model (RIPCO) }\end{array}$ & $\begin{array}{l}\text { - Popular due to lack of financial resources, } \\
\text { - Conducts early stage research, } \\
\text { - Licenses results to big companies which finish the research } \\
\text { and commercialize the product. }\end{array}$ & $\begin{array}{l}0 \\
0 \\
+1\end{array}$ \\
\hline $\begin{array}{l}\text { No research - } \\
\text { development only }\end{array}$ & $\begin{array}{l}\text { - Buys 'discarded' drugs from large companies, } \\
\text { - Completes the research on them, } \\
\text { - Commercializes the final product. }\end{array}$ & $\begin{array}{c}+1 \\
+1 \\
0\end{array}$ \\
\hline Pure licensing & $\begin{array}{l}\text { - Conducts activity in the initial stages of value chain, } \\
\text { - Licenses but does not sell property rights of their results to } \\
\text { other firms. }\end{array}$ & $\begin{array}{r}0 \\
+1\end{array}$ \\
\hline $\begin{array}{l}\text { Research service } \\
\text { companies }\end{array}$ & $\begin{array}{l}\text { - Provides research service, } \\
\text { - Covers a specific niche in the value chain, } \\
\text { - Two types based on specialization: Contract Research Organiza- } \\
\text { tion (CRO) - preclinical and clinical trials; } \\
\text { - Contract Manufacturing Organization (CMO) - biological prod- } \\
\text { ucts and chemical drugs. }\end{array}$ & $\begin{array}{c}+1 \\
0 \\
0 \\
0\end{array}$ \\
\hline $\begin{array}{l}\text { Initial Public } \\
\text { Offering (IPO) }\end{array}$ & $\begin{array}{l}\text { - Brand new companies without earnings, } \\
\text { - Valued by their ongoing researches and their publicly an- } \\
\text { nounced results, } \\
\text { - No room for exit strategy due to lack of revenues. }\end{array}$ & $\begin{array}{c}0 \\
0 \\
-1\end{array}$ \\
\hline
\end{tabular}

Notes: The assessment scale from -1 to +1 indicates the applicability to the ReSOLVE framework with the consideration of SMEs. -1: Prevents circular transition or not suitable for SMEs, 0: Neutral to circular transition, +1: Contributes to circular transition.

The spread of open business models shows that sharing knowledge has become a key pattern - even in an industry where the protection of intellectual properties plays a significant role. The common features of open models can be summarized into three aspects. First, the presence of shared innovation and collaboration is essential. Second, the application of IT becomes significant. Eventually, the rapid flow of information has led to higher customer awareness which has resulted in a demand for personalization (Frankenberger, Weiblen, \& Gassmann, 2013). These aspects indicate that the evolving digital revolution has a strong influence on pharmaceutical biotechnology (Murdoch \& Detsky, 2013). Thus, this analysis 
differentiates between regular open business models and the ones which operation highly depend on the use and management of data. This is a slight modification considering the classification of Segers (2017), who has treated open models under one umbrella.

Table 3. Regular open business models of the Belgian pharmaceutical biotech industry (source: selfmade based on Segers, 2017)

\begin{tabular}{|c|c|c|}
\hline Business model & Characteristics & Applicability \\
\hline $\begin{array}{l}\text { Open Innova- } \\
\text { tion based } \\
\text { R\&D }\end{array}$ & $\begin{array}{l}\text { - Appears when companies decide to focus more on their core } \\
\text { competencies and outsource their R\&D activities. }\end{array}$ & +1 \\
\hline Networked ${ }^{*}$ & $\begin{array}{l}\text { - The open form of the traditional fully integrated companies, } \\
\text { - Varying forms and intensity of partnership due to current needs, } \\
\text { - More efficient management of resources by leveraging assets of } \\
\text { other firms. }\end{array}$ & $\begin{array}{l}-1 \\
+1 \\
+1\end{array}$ \\
\hline $\begin{array}{l}\text { EFQM excel- } \\
\text { lence }\end{array}$ & $\begin{array}{l}\text { - European Foundation of Quality Management, } \\
\text { - Use of self-assessment according to certain criteria: the imple- } \\
\text { mentation of key activities, achievements. }\end{array}$ & 0 \\
\hline $\begin{array}{l}\text { Fully } \\
\text { diversified }\end{array}$ & $\begin{array}{l}\text { - Large company model, } \\
\text { - Expansion of core business to provide related products, } \\
\text { - The tools are in-licensing, collaboration, merger and acquisition. }\end{array}$ & $\begin{array}{c}-1 \\
0 \\
+1\end{array}$ \\
\hline IP-oriented & $\begin{array}{l}\text { - It is based on property rights and patents, } \\
\text { - The IP protection is a critical point, } \\
\text { - The company sells or licenses out all the items on its portfolio. }\end{array}$ & $\begin{array}{c}0 \\
0 \\
+1\end{array}$ \\
\hline $\begin{array}{l}\text { Repurposing } \\
\text { and technology } \\
\text { brokering }\end{array}$ & $\begin{array}{l}\text { - Repurposing model: Identifying a developing or existing mol- } \\
\text { ecule for one purpose and utilizing it for another (e.g. reposition- } \\
\text { ing old substances to new diseases) } \\
\text { - Patent management is a key activity, } \\
\text { - Technology brokering: Discovering a molecule on a company's } \\
\text { portfolio and introducing it to another. }\end{array}$ & $\begin{array}{c}+1 \\
0 \\
+1\end{array}$ \\
\hline $\begin{array}{c}\text { Distributed } \\
\text { partnering }\end{array}$ & $\begin{array}{l}\text { - Product Definition Companies (PDC) detect promising products } \\
\text { in development, } \\
\text { - They make acquisition in an early stage and find an application } \\
\text { for the product, } \\
\text { - Later, they sell it to pharmaceutical companies which finish the } \\
\text { development. }\end{array}$ & $\begin{array}{l}0 \\
+1 \\
0\end{array}$ \\
\hline $\begin{array}{l}\text { Outcome- } \\
\text { driven }\end{array}$ & $\begin{array}{l}\text { - Based on the "Pay for Performance" principle, } \\
\text { - Application of certain methods to measure performance, } \\
\text { - Considerable influence on pricing during patent protection pe- } \\
\text { riod of approved drugs, } \\
\text { - The main patterns are pricing and reimbursement. }\end{array}$ & $\begin{array}{c}+1 \\
0 \\
0 \\
0\end{array}$ \\
\hline
\end{tabular}

Notes: The assessment scale from -1 to +1 indicates the applicability to the ReSOLVE framework with the consideration of SMEs. -1: Prevents circular transition or not suitable for SMEs, 0: Neutral to circular transition, +1 : Contributes to circular transition. ${ }^{\star}$ Although the model includes two preferred components, they both contribute to the same principle (Optimize)

Table 3 demonstrates the assessment of the regular open biotech models. The 'Networked' business model is an example for the perception that single companies cannot efficiently 
manage all of the necessary resources needed to have control over the full value chain (Gay, 2014). In the time of closed business approaches, reaching the FIPCO model was the ultimate goal of starting ventures. However, a fully integrated structure would not fit the recent market trends in terms of cost- and time-effectiveness (Marcello, Carroll, Vadnerkar, \& Volini, 2015). In terms of circularity, 'Repurposing' and 'Technology brokering' business models are unique initiatives of this study. They do not only include beneficial elements; their whole intention is built upon the circular pattern of lifespan extension. They reflect the closed 'No research development only' approach. The difference is that the closed model focuses on the reuse of discarded research, while these ones aim at finding new purposes to already existing or developing molecules. Creating multiple values for old substances by applying them to new diseases saves a lot of energy and material which would be manifested into finding novel solutions. The 'Distributed partnering' model has some similarities with this concept. The exception is that it does not tend to make full product development. It only buys promising licenses to find them a possible application and resells them to large companies which finish the development (Roth \& Cuatrecasas, 2010). However, the role of this model could be controversial. On one hand, it extends the value chain by stepping into the process. This further increases the marginal costs of the final product. On the other hand, its specialized brokering activity could help to shorten the whole R\&D period by efficiently finding a product use.

After the elaboration on regular open biotech models, Table 4 shows the evaluation of the data-driven group. The 'Bundling' model is a more advanced version of the previously mentioned 'Networked' approach. Its uniqueness is to actively participate in cross-sectoral cooperation. A cross-industrial information flow would lead to the future of innovation networks and to a new level of efficient resource management. There is evidence that even small businesses can cooperate with large companies outside their industry (Segers, 2017). The 'Crowdsourcing' is yet employed by large firms, though it must be interpreted to small initiatives as well. The power of communities has always been a determining factor of social progress which seemed to fade away by the end of the 20th century. Nevertheless, their influence has started to prevail again and there are business models leveraging on their intangible community capital (e.g. energy cooperatives) (Fogarassy, Horvath, Kovacs, Szoke, \& Takacs-Gyorgy, 2017a). The contact with the global scientific community must be targeted by small biotech businesses. The next one is the 'Virtual collaboration' that offers a model with a core function of IT. The outsourced $R \& D$ activity plays a vital role in this approach. The real value is created through the organization of an intellectual virtual network with the goal of developing new drugs (Sabatier, Mangematin, \& Rousselle, 2010).

Another model with an advanced role of IT is the 'Software as service' which is entirely based on bioinformatics. It is similar to the 'Product as service' approach; a popular tool of CE. That Product-service system (PSS) promotes the usage of products instead of their ownership (Wastling, Charnley, \& Moreno, 2018). Related leasing models can be applied not only for products, but also for services. Agricultural consulting and healthcare present good examples for that. At these professions, machines examine plant diseases or patients and transfer data to experts who make the diagnosis. In some cases, the machines are equipped to conduct the diagnosis by themselves. This mechanism enables businesses to considerably reduce their resource use. In case of the 'Collaborative discovery' there are similarities to the 
regular 'Networked' model. The difference is that the former for focuses on tailor-made treatments. This form is highly preferred in CE because it does not address mass markets which are sources of a significant amount of waste. According to Segers (2017), collaborative businesses are predicted be the models of the future. Eventually, the similar 'Patient-centricity'

Table 4. Data-driven open business models of the Belgian pharmaceutical biotech industry (source: self-made based on Segers, 2017)

\begin{tabular}{|c|c|c|}
\hline Business model & Characteristics & Applicability \\
\hline Bundling & $\begin{array}{l}\text { - An innovation network based on cross-sectoral cooperation be- } \\
\text { tween biology, nanotechnology and computational sciences, } \\
\text { - Small firms make alliances with large companies outside their } \\
\text { own industry. }\end{array}$ & $\begin{array}{l}+1 \\
0\end{array}$ \\
\hline Crowdsourcing & $\begin{array}{l}\text { - It has been applied mostly by large firms so far, } \\
\text { - They launch challenges to mobilize external resources, } \\
\text { - Receive external ideas from the global scientific community via } \\
\text { virtual networks. }\end{array}$ & $\begin{array}{l}-1 \\
+1 \\
+1\end{array}$ \\
\hline $\begin{array}{l}\text { Virtual } \\
\text { collaboration }\end{array}$ & $\begin{array}{l}\text { - Small research groups employ external resources to work on } \\
\text { new drug candidates, } \\
\text { - The value lies in the creation of the network, } \\
\text { - Provides access to own resources and also receives to external } \\
\text { ones, } \\
\text { - IT is a key aspect, } \\
\text { - Such firms are fully dependent on their partners. }\end{array}$ & $\begin{array}{l}+1 \\
0 \\
+1 \\
+1 \\
-1\end{array}$ \\
\hline $\begin{array}{l}\text { Software as a } \\
\text { Service }\end{array}$ & $\begin{array}{l}\text { - A bioinformatics model, } \\
\text { - Provides consulting service and software to support data man- } \\
\text { agement and many activities, } \\
\text { - Reduces material intensity by the employed platforms. }\end{array}$ & $\begin{array}{l}+1 \\
+1 \\
+1\end{array}$ \\
\hline $\begin{array}{l}\text { Collaborative } \\
\text { discovery }\end{array}$ & $\begin{array}{l}\text { - Does not address mass product markets, } \\
\text { - Large company model, } \\
\text { - Provides service to individual patients, } \\
\text { - Designs innovative personalized or group-specific products, } \\
\text { - Generation of Big Data Bases by the virtual monitoring of cus- } \\
\text { tomers } \\
\text { - The collaboration with drug and diagnostics companies is es- } \\
\text { sential. }\end{array}$ & $\begin{array}{l}+1 \\
-1 \\
+1 \\
+1 \\
+1 \\
+1\end{array}$ \\
\hline $\begin{array}{l}\text { Patient-cen- } \\
\text { tricity }\end{array}$ & $\begin{array}{l}\text { - Avoids mass markets, } \\
\text { - Bioinformatics enables personalized treatments, } \\
\text { - Provides not only service but essential data to customers to } \\
\text { raise awareness, } \\
\text { - Involvement of patients in open innovation, } \\
\text { - Application of new technologies, } \\
\text { - Used by large firms. }\end{array}$ & $\begin{array}{l}+1 \\
+1 \\
+1 \\
0 \\
+1 \\
-1\end{array}$ \\
\hline
\end{tabular}

Notes: The assessment scale from -1 to +1 indicates the applicability to the ReSOLVE framework with the consideration of SMEs. -1: Prevents circular transition or not suitable for SMEs, 0: Neutral to circular transition, +1 : Contributes to circular transition. 
model is built upon the personalization of services. Since patients receive more information recently, they demand personal treatment forms. Concerning healthcare systems, it is one of the most urgent challenges (Saias \& Kapadia, 2016). The novelty of the model is the personal involvement of patients by crowd research, patient communities, focus groups etc.

The review of the Belgian pharmaceutical biotech industry introduced a diverse set of business models. Based on their presented features, the next section evaluates the applicability of the certain approaches to the ReSOLVE framework.

\section{Results and discussion}

\subsection{The circular evaluation of biotechnology business models}

Based on the circular features in biotechnology business models, Table 5 summarizes their evaluation according to the ReSOLVE criteria. The first observation is the entire lack of 'regeneration' attributes. Although single bio-tech models may have such specialization, it is not represented in the characteristics of the mainstream ones. In contrast, 'sharing' is a popular pattern. It comes from the fact that most of the small-scale models lease technology platforms or other services. This is the reason why 'optimization' occurs mostly in large company models. The company scale and profile lead to an interesting trade-off between the appearance of sharing and optimization. There is either a big company rationalizing its processes by outsourcing or small ventures providing platforms for that. The mutual application of sharing and optimization happens only when there is at least one more circular feature in the model.

Regarding the frequency of circular elements, open - and especially data-driven - business models apparently include more than the closed ones. An exceptional case within closed approaches is the 'No research - development only' model which closes the resource 'loop' of other companies by restoring their discarded materials. Similar loop influences appear at regular open models where patent management and technology brokering are key activities. However, the key feature that results in the multiple application of circular components is 'virtualization'. The employment of digital tools is a distinguishing attribute which applies only to data-driven open models. It occurs in several forms as virtual platforms for collaboration, data management, outsourcing tasks and as a customer channel for consulting. Virtualization allows material optimization also for small R\&D companies that already operate on a low resource intensity. Due to the upcoming digital revolution, this attribute will be a basic requirement not only in CE but in general business (Fleisch, Weinberger, \& Wortmann, 2015). Concerning biotech companies, the integration of IT enhances circular performance, since such firms include the most ReSOLVE elements. Eventually, 'exchange' is associated with the application of novel methods, services and technologies in production (Ellen MacArthur Foundation, 2015b). That pattern can only be found in data-driven open models. The innovative customer-oriented service of 'Collaborative discovery' and 'Patientcentricity' business models requires new processes and technologies which is a unique feature in the industry. 
Table 5. The evaluation of circularity criteria in biotechnology business models

\begin{tabular}{|c|c|c|c|c|c|c|}
\hline Business model & Regenerate & Sharing & Optimize & Loop & Virtualize & Exchange \\
\hline \multicolumn{7}{|l|}{ Product-based } \\
\hline Platform-based & & $\mathrm{X}$ & & & & \\
\hline Hybrid & & $\mathrm{X}$ & & & & \\
\hline $\begin{array}{l}\text { Royalty Income Pharmaceu- } \\
\text { tical Model (RIPCO) }\end{array}$ & & $\mathrm{X}$ & & & & \\
\hline $\begin{array}{l}\text { No research - development } \\
\text { only }\end{array}$ & & $\mathrm{X}$ & & $\mathrm{X}$ & & \\
\hline Pure licensing & & $\mathrm{X}$ & & & & \\
\hline Research service companies & & $\mathrm{X}$ & & & & \\
\hline \multicolumn{7}{|l|}{ Initial Public Offering (IPO) } \\
\hline $\begin{array}{l}\text { Open Innovation based } \\
\text { R\&D }\end{array}$ & & & $\mathrm{X}$ & & & \\
\hline Networked & & & $\mathrm{X}$ & & & \\
\hline \multicolumn{7}{|l|}{ EFQM excellence } \\
\hline Fully diversified & & & $\mathrm{X}$ & & & \\
\hline IP-oriented & & $\mathrm{X}$ & & & & \\
\hline $\begin{array}{l}\text { Repurposing and technology } \\
\text { brokering }\end{array}$ & & $\mathrm{X}$ & & $\mathrm{X}$ & & \\
\hline The distributed partnering & & & & $\mathrm{X}$ & & \\
\hline Outcome-driven & & $\mathrm{X}$ & & & & \\
\hline Bundling & & & & & $\mathrm{X}$ & \\
\hline Crowdsourcing & & & $\mathrm{X}$ & & $\mathrm{X}$ & \\
\hline Virtual collaboration & & $\mathrm{X}$ & $\mathrm{X}$ & & $\mathrm{X}$ & \\
\hline Software as a Service & & $\mathrm{X}$ & $\mathrm{X}$ & & $\mathrm{X}$ & \\
\hline Collaborative discovery & & $\mathrm{X}$ & $\mathrm{X}$ & & $\mathrm{X}$ & $\mathrm{X}$ \\
\hline Patient-centricity & & $\mathrm{X}$ & $\mathrm{X}$ & & $\mathrm{X}$ & $\mathrm{X}$ \\
\hline
\end{tabular}

Notes: $\mathrm{X}$ indicates which ReSOLVE element appears in the certain business model.

It is interesting to discover the paradoxical nature of technologies in business model research. On one hand, it is clear that technologies sell better with appropriate business models (Chesbrough \& Rosenbloom, 2002). On the other hand, businesses still need technologies to develop those models (Baden-Fuller \& Haefliger, 2013). This paper argues that the role of technologies must be distinguished according to their application. In the upcoming digital era, the relevance of technologies to operate businesses surpasses the significance of the ones they sell. Rifkin (2014) emphasizes the importance of technologies to achieve this economic paradigm shift. He expects novel technologies to trigger the fourth industrial revolution and considerably cut marginal costs by excluding unnecessary actors from the value chain. Thus, stating that the world does not need new technologies, but instead business models (Pauli, 
2009) may be a little extreme. The case of biotech businesses proved the employment of virtual platforms a key factor. The analysis showed how virtualization enables the application of multiple circular features for them. Digital appliances are essential to collaborate with partners and to provide services for customers.

Based on these findings, the following sub-section summarizes the detected circular features of biotech business models into a conceptual framework.

\subsection{A conceptual business model best practice for circular transitions in biotechnology}

As an organizational scheme for the detected circular characteristics at biotech businesses, the present section employs the Business Model Canvas (BMC) of Osterwalder and Pigneur (2010). The authors have built a conceptual model which allows researchers to analyze the logic behind a firm's profitability. It consists of nine building blocks covering the fundamental company elements to create, deliver and capture value. As it was described at the evaluation, business must also include additional attributes which does not contribute directly to CE. These are supporting elements of the business model itself which string together the operation of circular components. Since a business model cannot be entirely based on circular features, their application is necessary for the appropriate function (Oghazi \& Mostaghel, 2018). The following paragraphs review the building blocks of the BMC and indicate the fitting circular and supporting business model elements.

\section{Value proposition}

Before elaborating on circular biotech value propositions, it is necessary to interpret the business model concept in a wider context. Boons and Lüdeke-Freund (2013) highlight four requirements towards business models for sustainability. This study draws attention to the very first, which is the balance of the proposed value regarding economic, social and environmental dimensions. Following this logic in circular business models, Kraaijenhagen et al. (2016) introduces a BMC with segregated social, environmental and economic value proposition platforms. This paper puts emphasis on the separated nature of these aspects, even if they are likely to interact with each other.

The most important social value of certain biotech companies is their contribution to a socio-economic paradigm shift. The previous stages of industrial revolution - especially the second - have functioned as an engine to economic growth. However, the mass production of industrialization has affected humanity also in a harmful way. Industry experts predict that the fourth wave of industrial revolution will return to society's demand for individual, unique products (Horvath, 2018). Providing patient-centered treatments has become an emerging trend also in the pharmaceutical biotech industry (Swan, 2009; Agoulnik, 2016). Since this phenomenon goes along with a mass amount of required data, the role of IT will be significant in this field. Thus, pharmaceutical biotech businesses must take part in the upcoming Big Data revolution. These systems will be essential tools to develop a comprehensive database on customer's biological features and health conditions. They could also be used during product testing periods to monitor the effects of the drugs (Murdoch \& Detsky, 2013). 
Concerning environmental values, the presence of SMEs has become highly relevant. Earlier, the fully integrated value chain has been the long-term goal of biotech businesses. It has meant a dominant market position and it was an efficient way to manage resources. Nowadays, companies tend to focus on their core competencies and to utilize external resources by outsourcing other activities (mostly R\&D) (Sabatier et al., 2012). As SMEs have started to cover these market niches, material leakages of the value chain have been reduced. Moreover, some biotech businesses contribute to environmental and circular values by their company profile. The analysis showed that certain initiatives specialize on reusing molecules which have been discarded by other companies. Another interesting version of that is repurposing old molecules to cure new diseases (Roth \& Cuatrecasas, 2010). Reusing would save the energy and material manifested in the research thus far, while repurposing would decrease the extra efforts of developing new drugs.

The separation of the previous aspects demonstrates how the social and environmental values of a business concern collective needs. Although they generate economic benefits as well, the direct economic value proposition of biotech SMEs concern other companies. SMEs provide R\&D services to large biotechnology firms. Due to their specialization, they can shorten the R\&D period which would take longer and be more expensive for big companies (Sabatier, Mangematin, \& Rousselle, 2010). This pattern has made SMEs the major facilitators of innovation in biotech industry. The most advanced biotech ecosystems show a high density of such initiatives (Gassmann \& Keupp, 2007).

\section{Customer segments}

The target group of pharmaceutical biotech SMEs is simple. Since they specialize on outsourced activities of large firms, the customer segment consists mostly of these companies. This pattern differs at non-pharmaceutical companies, where customers come from a broader horizon. Although SMEs get in contact with the end customer, it is the big pharma company to buy the drugs and to commercialize them (Lipton \& Nordstedt, 2016). The circular transition in this field could come from the selection of customers. Lewandowski (2016) offers to choose business partners by their activity or service (e.g. green procurement). Since biotech SMEs are engaged to $\mathrm{B} 2 \mathrm{~B}$ segments, they can consider this criterion by selecting who do they work for. Circular biotech SMEs must find clients who avoid mass markets and target individuals with patient-centered treatments. It enables SMEs to provide additional consulting and monitoring services related to their core product.

\section{Channels}

Due to the simple nature of customer segmentation, the traditional channels of pharma biotech SMEs are not complex either. According to the previous practice, the communication to large firms has been conducted through personal meetings. The acquaintance of new customers has been made via professional platforms (e.g. conferences and workshops). The analysis indicated how virtual contact - which is preferred by CE - is spreading across the biotech industry. The novel communication channels allow companies to target customers on a global level (Andersson \& Stone, 2017). However, this phenomenon poses a challenge because of differing drug development standards of countries. China and the UK 
have a relatively less strict legislation framework comparing to other parts of the world. Researchers predict that the varying circumstances of drug development might steer outsourced biotech activities to a global scale (Tölle \& Herbst, 2016). This is due to the more efficient flow of information through digital platforms. Thus, in a global competition, it is essential for biotech SMEs to employ virtual platforms and extend their customer network to a global level.

\section{Customer relationship}

This is an interesting aspect in case of biotech SMEs. Normally, they do not make long-term commitment to their customers. They work on a drug research project and once the results are sold, they move to another client. However, during the cooperation, the contact remains constant as the SME needs continuous feedback on the partial outcomes. Since this segment is about the nature of the relationship, it offers a lack of potential to integrate circular measures.

\section{Revenue streams}

SMEs are mostly launched by the help of private investors. The major bottleneck of their operation is the duration of their research and the uncertainty of the outcomes. Turning to business angels or venture capitalists in such period is a popular solution in business (Bonnet \& Wirtz, 2012; Kang, 2018). Moreover, Mangematin et al. (2003) have found a French biotech SME approach which is suitable to cover operational expenses. That model engages in short-term projects that generate results sooner. It enables the firm to cover its running costs. Sabatier et al. (2012) have introduced the 'Software as Service' bioinformatics model that provides consultation and data management. Since the commission for such activities means a continuous revenue for companies, that model is suggested to be integrated in the business. In that case, the critical period lasts until finding the customer base to maintain the operation. Eventually, an efficient way to shorten the research period and to gain revenues earlier is a previously highlighted circular pattern. Companies can acquire discarded research of other firms. Thus, the research does not start from the bottom. The same applies to the model which aims at repurposing old molecules. These examples show how a circular activity can beneficially influence revenue streams.

\section{Key resources}

For companies doing $\mathrm{R} \& \mathrm{D}$, intellectual property is the ultimate resource. This is valid for such firms in general. The personnel to conduct research is a significant asset, since it will generate the future patents (Fernald, Pennings, \& Claassen, 2015). To enhance circularity, the patents under development can come from discarded research of other firms or from repurposing existing molecules. For companies engaged in virtual collaboration, an online platform and a digital software are essential properties.

\section{Key activities}

The possible activities of biotech SMEs are narrowed down to two options: R\&D and consulting. The other additional activities come from these two. The R\&D is best to be conducted 
in a collaborative partnership with the key partners and customers to create a value circle and to keep materials within a closed loop (Aminoff et al., 2017). For companies engaging in the previously mentioned reuse or repurpose models, patent management and technology brokering are key activities. Eventually, data management must be in focus due to the upcoming data-driven digital era.

\section{Key partners}

Since most biotech SMEs function as a bridge between academia and large firms, their key partners come from universities and small research groups. These partners propose the initial idea which can be further researched and developed into a patent (Segers, 2017). Due to the broadening horizon of pharmaceutical biotech specification, a cross-sectoral partnership is required for several reasons. The expertise of non-industrial partners could be fundamental to maintain the core activity of the business (Palmer \& Chaguturu, 2017). Tailor-made treatments have become important in many health-related sectors (e.g. nutrition, sport). The collaboration with these interacting industries contributes to sharing knowledge. It would be a competitive advantage to develop products based on the specifications of multiple sectors. Eventually, a company with a computational profile is a key partner in the development and maintenance of a virtual platform for the business.

\section{Cost structure}

The major source of costs is to conduct R\&D. It exponentially increases along the process. The considerable expenses occur at the final stages consisting of test and trials. Thus, SMEs must focus on the initial parts of the research or apply to previously recommended strategies (e.g. short-term projects). At last, for businesses in virtual consulting the development/ acquisition of a software and its maintenance will be another cost item.

\section{A Business Model Canvas featuring circular options for biotechnology SMEs}

As a summary of the previous paragraphs, Table 6 summarizes circular business model attributes for SMEs in the pharmaceutical industry. The concerned ReSOLVE features are indicated in brackets at the certain elements, according to which one they represent. The structure follows the BMC logic of Osterwalder and Pigneur (2010) and adds a segregated context to the value proposition block based on Kraaijenhagen et al. (2016).

The outcome of the model is dedicated to industry stakeholders and entrepreneurs who tend to enter the pharmaceutical branch with a starting venture. The classification of the certain business model building blocks indicates how many possibilities the different categories offer for circular transition. The dominance of "Value Creation" (with 8 circular elements) is due to the fact that the category consists of the company's internal processes. The second most intense group was the "Value Proposition" by featuring 6 ReSOLVE components. This aspect is the most essential regarding circular businesses because it gives the purpose of a firm (Manninen et al., 2017). The rest is rather a collection of mechanisms around that value. The "Value Capture and Delivery" require further research to correspond with circularity and to enhance a company's competitiveness. Concerning "Value Delivery", the current study presented two opportunities. The application of virtual platforms can reduce the material and 


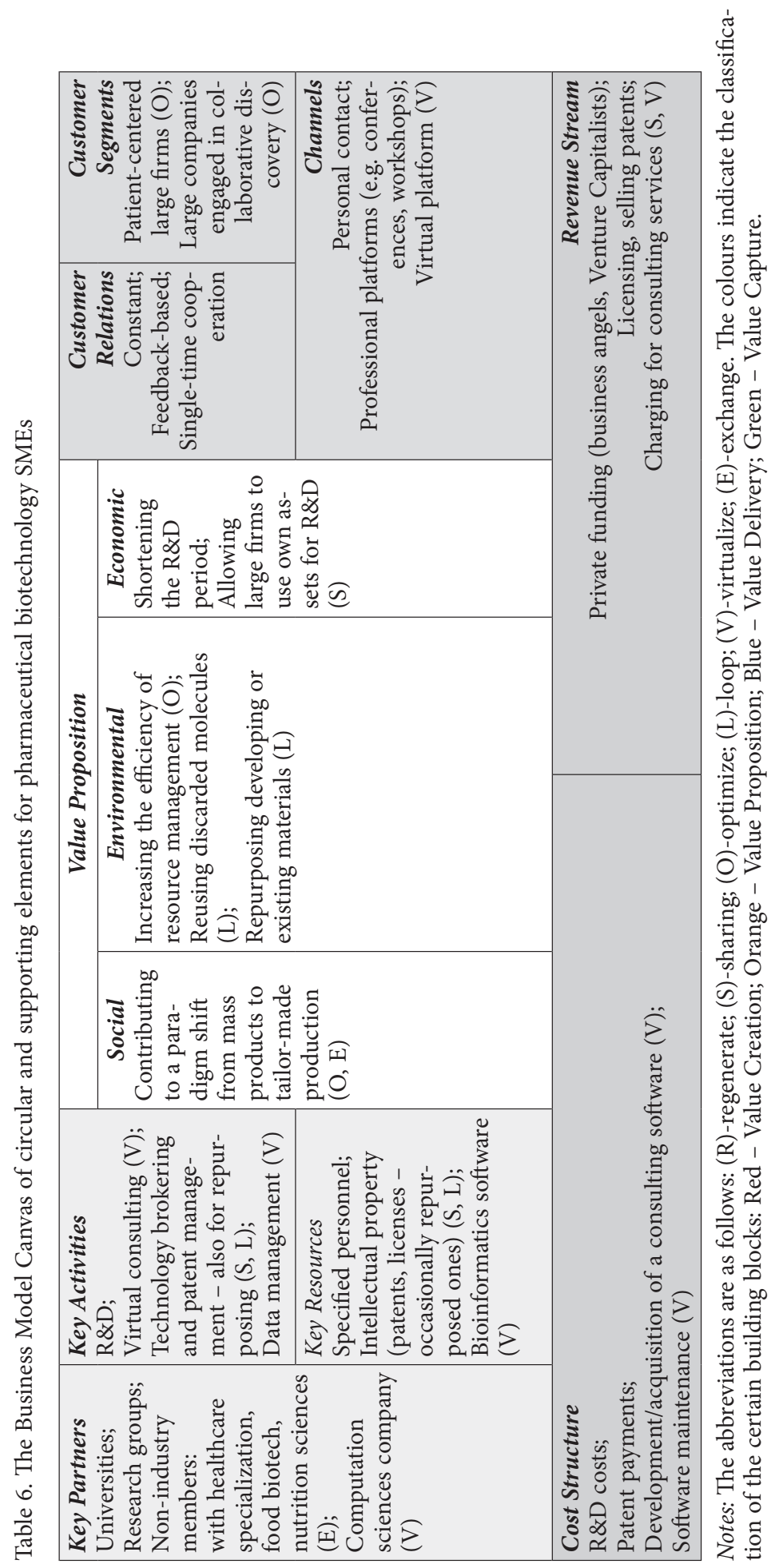


energy requirements of reaching customers. Furthermore, the B2B relationship of biotech SMEs allows them to work for firms which are engaged to circular values. However, the deeper elaboration on these aspects must be the subject of future research.

\section{Conclusions}

The current analysis indicated an interesting result regarding the future of economic systems in general. Businesses of the previous century faced major criticism due to their narrow economic interest and harmful social or environmental impacts. In the past 10-15 years, there was a slight change in this field due to the increasing role of business model innovation. This phenomenon influenced not only the financial sustainability of companies, but also prompted researchers to investigate how business models can extend their value proposition towards social and environmental dimensions. However, market stakeholders have not shown particular interest regarding such models and reaching the maximum profit has remained their ultimate goal. The fundamental intention of this paper was to show how this perspective becomes obsolete and what kind of threats it has for the ones who still cling to it. The reason for that is the changing nature of economy.

The Belgian biotechnology industry has presented a good example for adapting to circular economy principles in order to ensure market viability. Though the focus on that branch might have narrowed the study down to a single business environment, the examination of the topic has required a specific study area. Since it is one of the most innovative industries of the global economy, it has proved to be an excellent object to the analysis. The fact that even such advanced business ecosystems lack the appropriate tools in certain business model building blocks, gives purpose to future research on the topic. The upcoming studies must extend their focus to other biotechnology branches or target different industries. The lacking circular "Value Capture and Delivery" attributes are more general features than the "Value Creation and its Proposition". Therefore, their applicability does not necessarily depend on company profile.

Eventually, the study found a peculiar market niche steering businesses to a circular direction. It is the novel demand of customers regarding tailor-made products. The most innovative firms aim to avoid mass markets and address this emerging need. The only frontier to this phenomenon is the limited access to reliable and sufficient data. Mass production has been convenient before because universal products and services does not require considerable amounts of data. Nevertheless, customer orientation forces businesses to be aware of varying consumer behavior patterns. In case of health-related industries, an additional need is to discover the different health conditions and biological features of individual patients. This leads to the increasing role of data collection and to the generation of Big Data systems. Beyond the paradigm shift from closed to open biotechnology business models, the defined data-driven approaches seem to form a separate, superior category. The use of virtual elements apparently enhances the sustainable performance of the biotechnology sector. Thus, companies with an advanced IT application are expected to have definitive market advantage in the future. 


\section{Author contributions}

N. K. and C. F. had the initial idea of the manuscript. N. K. and P. Y. performed the literature material. B. H. and C. F. designed the research. B. H. wrote the paper with the supervision of C. F.

\section{Disclosure statement}

The authors declare no conflict of interest.

\section{References}

Agoulnik, I. I. (2016). Patient-centric healthcare of the future from the prospective of biomedical research and technology. Journal of Analytical \& Pharmaceutical Research, 2(4). https://doi.org/10.15406/japlr.2016.02.00028

Allianz. (2015). The sixth Kondratieff - long waves of prosperity. Analysis and Trends report. Allianz, Munich, DE. Retrieved from https://www.allianz.com/content/dam/onemarketing/azcom/Allianz com/migration/media/press/document/other/kondratieff_en.pdf

Aminoff, A., Valkokari, K., Antikainen, M., \& Kettunen, O. (2017). Exploring disruptive business model innovation fort the circular economy." In G. Campana, R. Howlett, R. Setchi, \& B. Cimatti (Eds.), Sustainable Design and Manufacturing 2017 - Smart Innovation, Systems and Technologies, 68, 526636. https://doi.org/10.1007/978-3-319-57078-5_50

Amit, R., \& Zott, C. (2012). Creating value through business model innovation. MIT Sloan Management Review, 53(3), 41-49.

Andersson, M., \& Stone, T.-A. (2017). Global sourcing and technical efficiency - a firm-level study on the ICT industry in Sweden. Journal of Business Economics and Management, 18(5), 877-896. https://doi.org/10.3846/16111699.2017.1356367

Armas-Cruz, Y., Gil-Soto, E., \& Oreja-Rodríguez, J. R. (2017). Environmental management in SMEs: organizational and sectoral determinants in the context of an Outermost European Region. Journal of Business Economics and Management, 18(5), 935-953. https://doi.org/10.3846/16111699.2017.1373375

Baden-Fuller, C., \& Haefliger, S. (2013). Business models and technological innovation. Long Range Planning, 46(6), 419-426. https://doi.org/10.1016/j.lrp.2013.08.023

Blecharz, P., \& Stverkova, H. (2014). Assessing the service quality in small and medium-sized companies. Actual Problems of Economics, 154(4), 206-217.

Bocken, N. M. P., Rana, P., \& Short, S. W. (2015). Value mapping for sustainable business thinking. Journal of Industrial and Production Engineering, 31(1), 67-81. https://doi.org/10.1080/21681015.2014.1000399

Bonnet, C., \& Wirtz, P. (2012). Raising capital for rapid growth in young technology ventures: when business angels and venture capitalists coinvest. Venture Capital - An International Journal of Entrepreneurial Finance, 14(2-3), 91-110. https://doi.org/10.1080/13691066.2012.654603

Boons, F., \& Lüdeke-Freund, F. (2013). Business model for sustainable innovation: state-of-the-art and steps to-wards a research agenda. Journal of Cleaner Production, 45, 9-19. https://doi.org/10.1016/j.jclepro.2012.07.007

Breitbarth, T., Schaltegger, S., \& Mahon, J. (2018). The business case for sustainability in retrospect: a Scandinavian institutionalism perspective on the role of expert conferences in shaping the emerging 
"CSR and corporate sustainability space". Journal of Public Affairs, 18(3). https://doi.org/10.1002/pa.1855

Brooks, A. L., Wang, S., \& Jambeck, J. R. (2018). The Chinese import ban and its impact on global plastic waste trade. Science Advances, 4(6). https://doi.org/10.1126/sciadv.aat0131

Chesbrough, H. (2007). Why companies should have open business models. MIT Sloan Management Review, 48(2), 22-28.

Chesbrough, H. (2010). Business model innovation: opportunities and barriers. Long Range Planning, 43(2-3), 354-363. https://doi.org/10.1016/j.lrp.2009.07.010

Chesbrough, H., \& Rosenbloom, R. (2002). The role of business model in capturing value from innovation: evidence from Xerox Corporation's technology spin-off companies. Industrial and Corporate Change, 11(3), 529-555. https://doi.org/10.1093/icc/11.3.529

Doranova, A. (2016). Regional Innovation Monitor Plus 2016 - Regional Innovation Report Flanders (Production related bio-technology). Technopolis Group: Brussels, Belgium. Retrieved from https:// ec.europa.eu/growth/tools-databases/regional-innovation-monitor/report/innovation

Ellen MacArthur Foundation. (2013). Towards The Circular Economy - Economic and business rationale for an accelerated transition. Ellen MacArthur Foundation, Cowes, UK. Retrieved from https://www. ellenmacarthurfoundation.org/assets/downloads/publications/

Ellen MacArthur Foundation. (2015a). Towards the circular economy: accelerating the scale-up across global supply chains. Ellen MacArthur Foundation, Cowes, UK. Retrieved from http://www3.weforum.org/docs/WEF_ENV_TowardsCircularEconomy_Report_2014.pdf

Ellen MacArthur Foundation. (2015b). Delivering the circular economy - a toolkit for policymakers. Ellen MacArthur Foundation, Cowes, UK. Retrieved from https://www.ellenmacarthurfoundation.org/ assets/downloads/publications/

Ernst \& Young. (2017). Beyond Borders Staying the Course - Biotechnological Report. Ernst and Young LLP, London, UK. Retrieved from https://www.ey.com/Publication/vwLUAssets/ey-biotechnologyreport-2017-beyond-borders-staying-the-course/\$File/ey-biotechnology-report-2017-beyond-borders-staying-the-course.pdf

Essenscia. (2017, 19-23 June). Belgium showcases expertise on Immunotherapy at the world's largest Biotechnology Conference. Press release on the BIO International Convention 2017 Conference in San Diego. Essenscia, Brussels, Belgium. Retrieved from http://www.essenscia.be/en/PressRelease/ Detail/16653

European Commission. (2015). Closing the loop - And EU action plan for the Circular Economy. European Commission, Brussels, BE. Retrieved from https://eur-lex.europa.eu/legal-content/EN/ $\mathrm{TXT} /$ ?uri=CELEX\%3A52015DC0614

Fernald, K., E. Pennings, \& Claassen, E. (2015). Biotechnology commercialization strategies: risk and return in interfirm cooperation. Journal of Product Innovation Management, 32(6), 971-996. https://doi.org/10.1111/jpim.12218

Fleisch, E., Weinberger, M., \& Wortmann, F. (2015). Business models and the internet of things. Interoperability and Open-Source Solutions for the Internet of Things, 9001, 6-10. https://doi.org/10.1007/978-3-319-16546-2_2

Fogarassy, Cs., B. Horvath, A. Kovacs, L. Szoke, \& Takacs-Gyorgy, K. (2017a). A circular evaluation tool for sustainable event management - an olympic case study. Acta Polytechnica Hungarica, 14(7), 161-177. https://doi.org/10.12700/APH.14.7.2017.7.10

Fogarassy, Cs., Horvath, B., \& Magda, R. (2017b). Business model innovation as a tool to establish corporate sustainability. Visegrad Journal on Bioeconomy and Sustainable Development, 6(2), 50-58. https://doi.org/10.1515/vjbsd-2017-0009

Frankenberger, K., Weiblen, T., \& Gassmann, O. (2013). Network configuration, customer centricity, 
and performance of open business models: a solution provider perspective. Industrial Marketing Management, 42(5), 671-682. https://doi.org/10.1016/j.indmarman.2013.05.004

Gassmann, O., \& Keupp, M. M. (2007). The competitive advantage of early and rapidly internationalising SMEs in the biotechnology industry: a knowledge-based view. Journal of World Business, 42(3), 350-366. https://doi.org/10.1016/j.jwb.2007.04.006

Gauthier, C., \& Gilomen, B. (2016). Business models for sustainability: energy efficiency in urban disctricts. Organization \& Environment, 29(1), 124-144. https://doi.org/10.1177/1086026615592931

Gay, B. (2014). Open innovation, networking, and business model dynamics: the two sides. Journal of Innovation and Entrepreneurship, 3, 2. https://doi.org/10.1186/2192-5372-3-2

Hay, M., Thomas, D. W., Craighead, J. L., Economides, C., \& Rosenthal, J. (2014). Clinical development success rates for investigational drugs. Nature Biotechnology, 32(1), 40-51. https://doi.org/10.1038/nbt.2786

Horvath, B. (2018). The recognition of resource use through industrial development from a social perspective. Studia Mundi - Economica, 5(1), 68-78.

Horvath, B., Mallinguh, E., \& Fogarassy, Cs. (2018). Designing business solutions for plastic waste management to enhance circular transitions in Kenya. Sustainability, 10(5), 1664. https://doi.org/10.3390/su10051664

Johnson, M., Christensen, C., \& Kagermann, H. (2008). Reinventing your business model. Harvard Business Review, 86(12), 45-48.

Kang, H. D. (2018). A Start-up's R\&D stages and the evolution of financing sources: evidence from the biotechnology industry. Entrepreneurship Research Journal, 8(3), 1-19. https://doi.org/10.1515/erj-2017-0159

Kola, I., \& Landis, J. (2004). Can the pharmaceutical industry reduce attrition rates? Nature Reviews Drug Discovery, 3, 711-716. https://doi.org/10.1038/nrd1470

Kraaijenhagen, C., van Open, C., \& Bocken, N. (2016). Circular business - collaborate and circulate. Ecodrukkers: Nieuwkoop, Netherlands.

Lewandowski, M. (2016). Designing the business models for circular economy - towards the conceptual framework. Sustainability, 8(1), 43. https://doi.org/10.3390/su8010043

Lipton, S., \& Nordstedt, C. (2016). Partnering with big pharma - what academics need to know. Cell, 165(3), 512-515. https://doi.org/10.1016/j.cell.2016.04.021

Mangematin, V., Lemarié S., Boissin J., Catherine D., Corolleur F., Coronini R., \& Trommetter, M. (2003). Development of SMEs and heterogeneity of trajectories: the case of biotechnology in France. Research Policy, 32(4), 621-638. https://doi.org/10.1016/S0048-7333(02)00045-8

Manninen, K., Koskela, S., Antikainen, R., Bocken, N., Dahlbo, H., \& Aminoff, A. (2017). Do circular economy business models capture intended environmental value propositions? Journal of Cleaner Production, 171, 413-422. https://doi.org/10.1016/j.jclepro.2017.10.003

Marcello, R., Carroll, G., Vadnerkar, G., \& Volini, A. (2015). Executing an open innovation model: cooperation is key to competition for biopharmaceutical companies. Deloitte Center for Health Solutions: Washington, USA.

Mentink, B. (2014). Circular business model innovation: a process framework and a tool for business model innovation in a circular economy (Master Thesis). Delft University of Technology \& Leiden University, Leiden, The Netherlands.

Micek, G., Gleadle, P., \& Dawidko, P. (2014). The role of institutional context in the development of the SME Biotech sector in Poland. Studies of the Industrial Geography Commission of the Polish Geographical Society - Contemporary issues in Polish industrial Geography, 25, 132-150.

Murdoch, T. B., \& Detsky, A. S. (2013). The inevitable application of Big Data to health care. JAMA, 
309(13), 1351-1352. https://doi.org/10.1001/jama.2013.393

Oghazi, P., \& Mostaghel, R. (2018). Circular business model challenges and lessons learned - an industrial perspective. Sustainability, 10, 739. https://doi.org/10.3390/su10030739

Osterwalder, A., \& Pigneur, Y. (2010). Business model generation: a handbook for visionaries, game changers, and challengers. Hoboken, USA: John Wiley and Sons.

Palmer, M., \& Chaguturu, R. (2017). Academia-pharma partnerships for novel drug discovery: essential or nice to have? Expert Opinion on Drug Discovery, 12(6), 537-540. https://doi.org/10.1080/17460441.2017.1318124

Pauli, G. (2009). Blue Economy - 10 years, 100 innovations, 100 million jobs. Paradigm Publications, Brookline, US.

Pisano, G. (2006). Can science be a business? Lessons from biotech. Harvard Business Review, 84(10), 114-125.

Ramkumar, S., Kraanen, F., Plomp, R., Edgerton, B., Walrecht, A., Baer, I., \& Hirsch, P. (2018). Linear risks. Circle Economy, Amsterdam, The Netherlands.

Rifkin, J. (2014). The zero marginal cost society: the internet of things, the collaborative commons, and the eclipse of capitalism. New York, USA: St. Martin's Press.

Roth, D., \& Cuatrecasas, P. (2010). The distributed partnering model for drug discovery and development. Kansas City, US: Kauffman - The Foundation of Entrepreneurship.

Sabatier, V., Craig-Kennard, A., \& Mangematin, V. (2012). When technological discontinuities and disruptive business models challenge dominant industry logics: insights from the drug industry. Technological Forecasting \& Social Change, 79, 949-962. https://doi.org/10.1016/j.techfore.2011.12.007

Sabatier, V., Mangematin, V., \& Rousselle, T. (2010). From recipe to dinner: business model portfolios in The European biopharmaceutical industry. Long Range Planning, 43, 431-447. https://doi.org/10.1016/j.lrp.2010.02.001

Saias, P., \& Kapadia, A. (2016). CROs, convergence, and commercial opportunities - how industry convergence is creating win/win opportunities for contract research and life sciences organizations. KPMG: Delaware, USA.

Schaltegger, S., Hansen E., \& Lüdeke-Freund, F. (2016). Business models for sustainability: origins, present research, and future avenues. Organization and Environment, 29(1), 3-10. https://doi.org/10.1177/1086026615599806

Schaltegger, S., Lüdeke-Freund, F., \& Hansen, E. (2012). Business cases for sustainability: the role of business model innovation for corporate sustainability. International Journal of Innovation and Sustainable Development, 6(2), 95-119. https://doi.org/10.1504/IJISD.2012.046944

Scott, J. T. (2013). The sustainable business a practitioner's guide to achieving long-term profitability and competitiveness (1st ed.). Abingdon, UK: Routledge.

Segers, J. P. (2015). The interplay between new technology based firms, strategic alliances and open innovation, with-in a regional systems of innovation context. The case of the biotechnology cluster in Belgium. Journal of Global Entrepreneurship Research, 5, 16. https://doi.org/10.1186/s40497-015-0034-7

Segers, J. P. (2017). Biotecnology business models: Catch-22 or best of both worlds? Working Paper, Hogeschool PXL, Hasselt, Belgium.

Swan, M. (2009). Emerging patient-driven health care models: an examination of health social networks, consumer personalized medicine and quantified self-tracking. International Journal of Environmental Research and Public Health, 6(2), 492-525. https://doi.org/10.3390/ijerph6020492

Teece, D. J. (2010). Business models, business strategy and innovation. Long Range Planning, 43(2-3), 172-194. https://doi.org/10.1016/j.lrp.2009.07.003 
Tölle, J., \& Herbst, F. K. (2016). The business model of biotech SMEs: how do biotech SMEs cope with the industry's challenges? (Master Thesis). Umeå School of Business and Economics, Umeå, Sweden.

Wach, K. (2015). Small and medium-sized enterprises in the modern economy. In M. R. C. Loera, \& A. Marianski (Eds.), The challenges of management in turbulent times: global issues from local perspective (pp. 77-101). Universidad de Occidente, Los Mochis, Mexico.

Wastling, T., Charnley, F., \& Moreno, M. (2018). Design for circular behaviour: considering users in a circular economy. Sustainability, 10(6), 1743. https://doi.org/10.3390/su10061743

World Business Council for Sustainable Development (WBCSD). (2017). 8 Business cases for the circular economy. World Business Council for Sustainable Development, Geneva, Switzerland.

Zott, C., Amit, R., \& Massa, L. (2011). The business model: recent developments and future research. Journal of Management, 37(4), 1019-1042. https://doi.org/10.1177/0149206311406265 